\title{
SMALL-SCALE STRAIN MEASUREMENTS ON A GLACIER SURFACE
}

\author{
By S. C. Colbeck*
}

(Geophysics Group, University of Washington, Seattle, Washington 98105, U.S.A.)

and R. J. Evans

(Civil Engineering Department, University of Washington, Seattle, Washington 98105, U.S.A.)

\begin{abstract}
Surface deformations in the neighborhood of a crevasse field were measured over short $(3 \mathrm{~m})$ gage lengths in order to study flow conditions associated with crevasse formation. The results obtained were unusual in that they were inconsistent with large-scale results found by previous workers. It was concluded that the presence of small-scale surface effects, such as fractures, pot-holes and healed crevasses give rise to small-scale deformation fields with large spatial and temporal variations and that there is a lower limit of gage length below which deformation measurements pertinent to regional flow phenomena cannot be made. This lower limit is apparently an order of magnitude greater than the spacing of the features which give rise to localized effects.

RÉsumé. Mesures de déformations à petite échelle à la surface d'un glacier. Les déformations de la surface dans le voisinage d'une zone de crevasses ont été mesurées sur de courtes longueurs $(3 \mathrm{~m})$ en vue d'étudier les conditions d'écoulement associées à la formation des crevasses. Les résultats obtenus ont été étranegs en ce sens qu'ils n'étaient pas cohérents avec les résultats à grande échelle obtenus par les précédents chercheurs. On en conclut que la présence d'effets de surface à petite échelle tels que fractures, marmites et crevasses cicatrisées donne naissance à des champs de déformation à petite échelle avec de grandes variations dans l'espace et dans le temps et qu'il y a une limite inférieure des longueurs mesurées en dessous de laquelle les mesures de déformation convenables pour le phénomène d'écoulement d'ensemble ne peuvent plus être faites. Cette limite inférieure est apparement d'un ordre de grandeur supérieur à l'espacement des accidents qui donnent naissance à des effets localisés.

Zusammenfassung. Engmaschige Deformationsmessungen auf einer Gletscheroberfläche. Die Oberflächendeformationen in der Nachbarschaft eines Spaltengebietes wurden in kurzen Abständen ( $3 \mathrm{~m})$ gemessen, um die mit der Spaltenbildung verbundenen Fliessvorgänge zu untersuchen. Die erhaltenen Resultate waren insofern ungewöhnlich, als sie mit den Ergebnissen weitmaschiger Messungen früherer Autoren nicht übereinstimmten. Es wurde geschlossen, dass das Vorhandensein kleinteiliger Erscheinungen an der Oberfläche, wie Brüche, Gletschertöpfe und wieder geschlossene Spalten, fein strukturierte Deformationsfelder mit grossen räumlichen und zeitlichen Schwankungen bewirkt und dass es eine untere Grenze für die Messabstände gibt, unter der Deformationsmessungen in Abhängigkeit von regionalen Fliesserscheinungen nicht durchgeführt werden können. Diese untere Grenze ist sichtlich um eine Ordnung grösser als die Dimension der Erscheinungen, welche örtliche Effekte hervorrufen.
\end{abstract}

THE study of crevasse formation and propagation provides information on the overall flow of the glacier and the tensile properties of glacier ice. The earliest theoretical contribution was that of Hopkins ( 1862 ) who, from considerations of statics, related crevasse orientation to the forces causing motion. More recently, Nye (1952) used Glen's flow law in a laminar flow model to investigate the occurrence of crevasse patterns and was able to predict realistic crevasse depths.

Field measurements were made by Meier (Meier and others, I957; Meier, 1960) who investigated the formation of transverse crevasses on the Saskatchewan Glacier and on the Greenland ice sheet. Meier measured the motion of stakes spaced at distances varying from 50 to $200 \mathrm{~m}$, these distances being of the order of the existing crevasse spacing. He concluded that the critical extending strain-rate for the initiation of a transverse crevasse was o.o I year ${ }^{-1}$. Holdsworth (I969) confirmed the results obtained by Meier. Lachenbruch (I96I) constructed a model of tension cracks in geological materials; this model predicts reasonable depths and spacings of crevasses in glaciers.

The purpose of this note is to discuss small-scale surface strain measurements made on the Blue Glacier, Washington, during the summers of 1967 and 1968 . The apparatus used for

* Present affiliation: U.S. Army Cold Regions Research and Engineering Laboratory, Hanover, New Hampshire 03755 , U.S.A. 
these measurements is described in some detail elsewhere (Colbeck and Evans, 1969) and will not be discussed here. Large spatial variations of surface strain were found and these results lead to conclusions which are considered to be relevent to the study of small-scale glacier flow phenomena. Local flow phenomena considerably different from regional phenomena have previously been recorded. Meier (I960) measured large velocity fluctuations on the Saskatchewan Glacier over short time intervals and even measured backward motion; similarly, large fluctuations in the rate of basal sliding have been measured in ice tunnels on the Blue Glacier. Lliboutry ( 1969 ) states that study of glacier dynamics necessitates smoothing over local fluctuations and that small-scale information is not pertinent to regional flow phenomena. The lower limit of the gage length for deformation measurements which will provide useful information for glacier analysis is certainly an important consideration.

A transverse crevasse field exists on the lower Blue Glacier in which the crevasse spacing is consistently $12 \mathrm{~m}$ over a total distance of about $150 \mathrm{~m}$. The regularity of the spacing

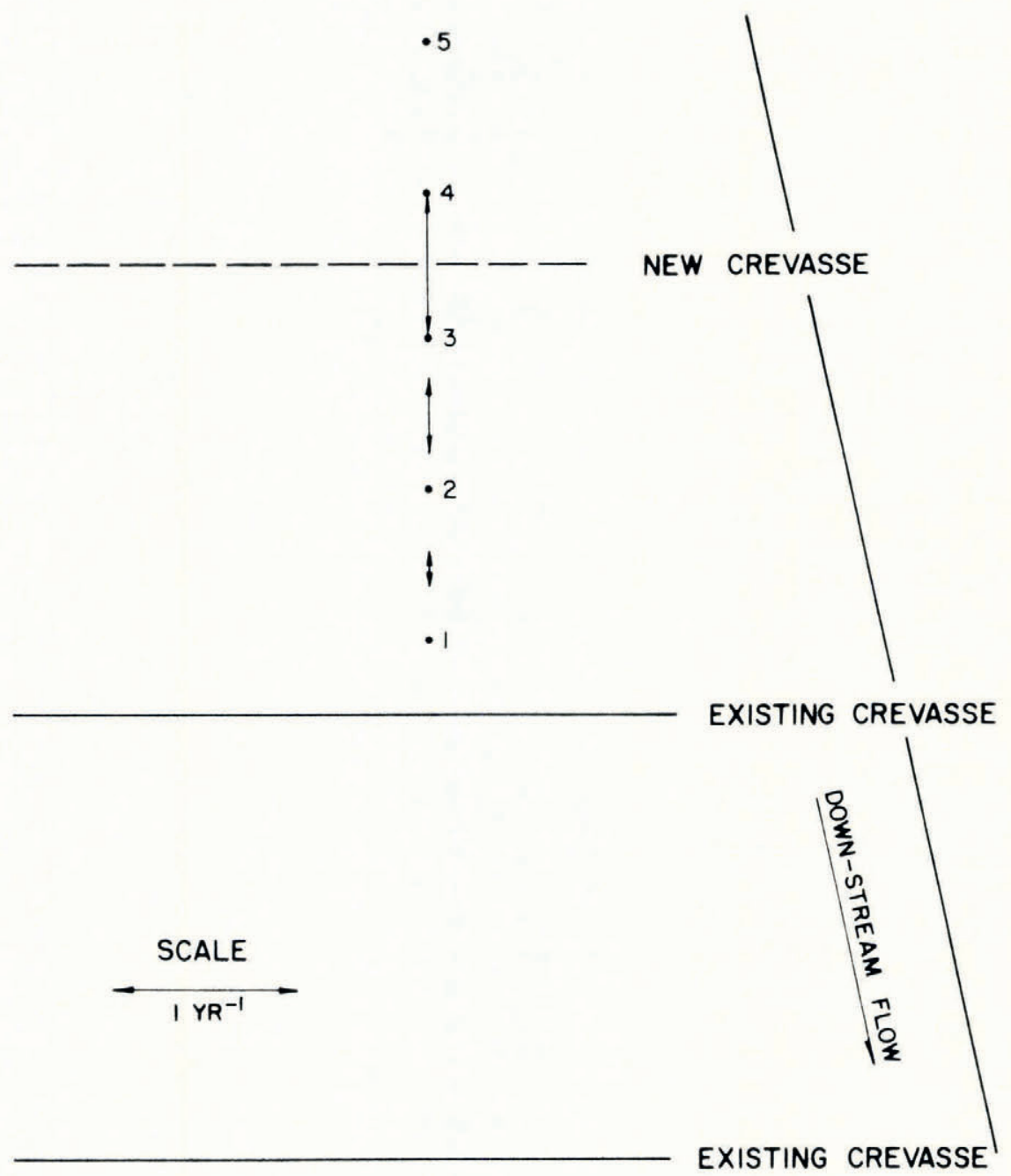

Fig. 1 . Position of stakes and marginal crevasses. 
suggests that crevasse formation is associated with a definite state of deformation. Accordingly, it was decided to attempt to measure the state of deformation of the glacier surface on a small scale and in the immediate vicinity of a forming crevasse by securing wood stakes in the surface at an initial spacing of $3 \mathrm{~m}$ and measuring their relative displacement directly.

A pilot project was planned for the summer of 1967 ; however, due to the late melt, the transverse crevasse field, although below the equilibrium line, was still covered with snow by the end of July. Since the technique for securing the stakes in the surface required that the ice be free of snow, measurements were made in a snow-free marginal crevasse field. A single line of five stakes was placed up-stream from the last crevasse so that, if the existing spacing were continued, the next crevasse should form between stakes 3 and 4 (see Fig. I). For three weeks no strain-rates greater than the inherent errors $( \pm \mathrm{I} \mathrm{mm})$ in the measuring techniques were computed. Subsequently, however, a large extension between stakes 3 and 4
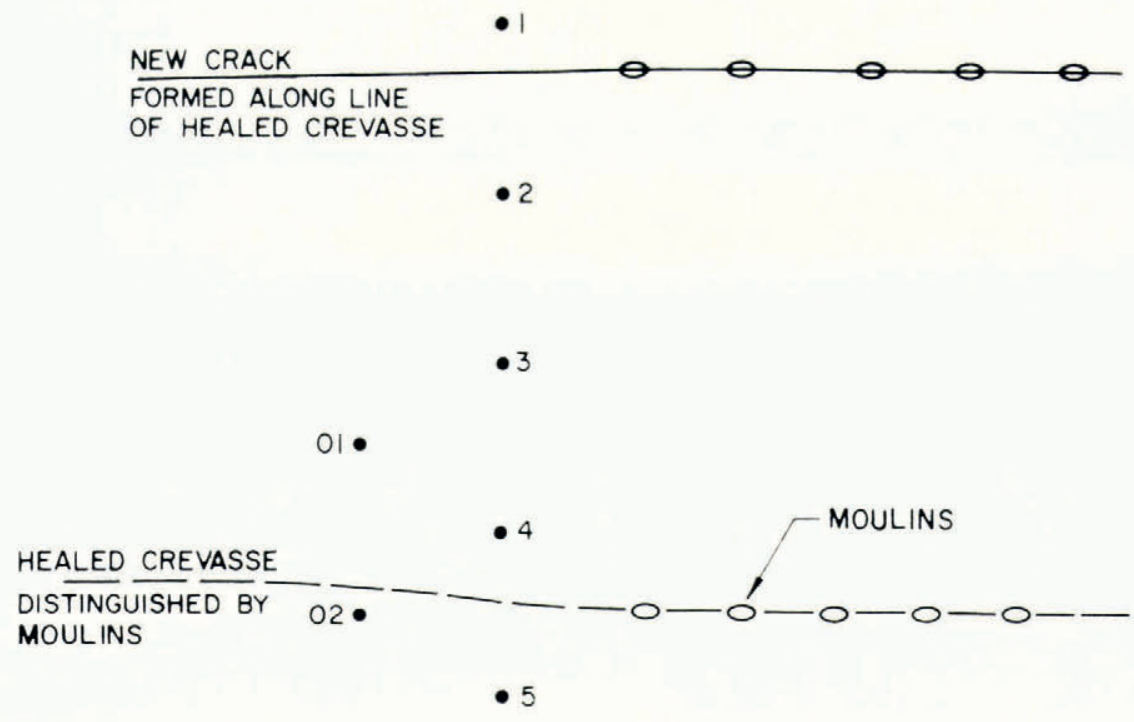

03
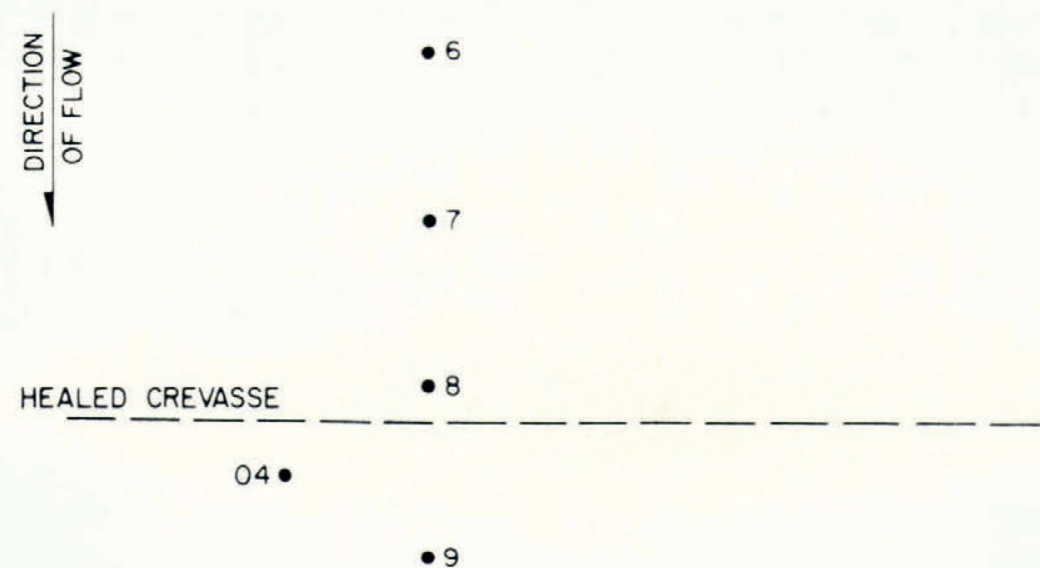

Fig. 2. Position of stakes and transverse crevasses. 
occurred, corresponding to a strain-rate of about 0.8 year ${ }^{-1}$. After two days a new fracture was found between stakes 3 and 4 . One year later, during the summer of 1968 , this fracture had opened to form a crevasse.

On the basis of this pilot project we were encouraged to plan a more complete investigation for the summer of 1968 . The measuring technique was improved so that distances between stakes could be measured to an accuracy of o. I mm using dial micrometers mounted on a rigidly supported invar bar. The pattern of stakes placed at the upper end of the transverse crevasse field is shown in Figure 2. Stakes were placed so that, if the regularity of the spacing were continued, the next crevasse would open between stakes 4 and 5 .

Measurements were taken over a period of 3 weeks, one week of which was needed to secure the stakes firmly (see Colbeck and Evans (r969) for details). During this first week the measurements were not considered to be accurate. Subsequently, consistent yet unusual results were obtained.

Figures 3,4 , and 5 represent three typical strain results. Figure 3 shows the strain between stakes $\mathrm{I}$ and 2 ; the strain-rate is linearly extensional and undergoes an abrupt increase at day 8. Concurrently, a fracture developed between these stakes. Figure 4 shows the strain

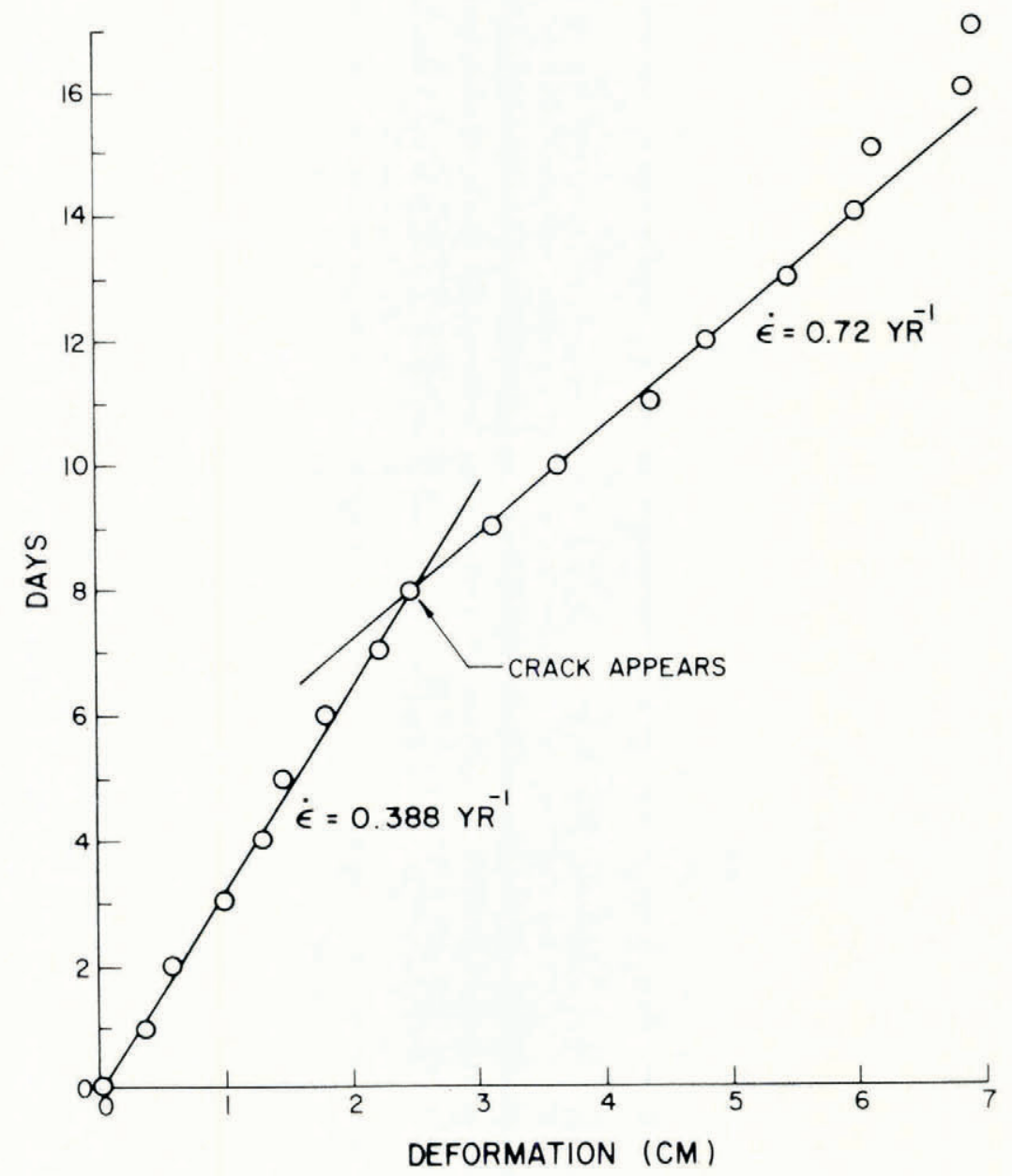

Fig. 3. Deformation between stakes I and 2. 
between stakes 8 and 9, which is uniformly compressive while Figure 5 shows that the strain between stakes 6 and 7 is extensional for the first 6 days and then changes to become compressive. It should be noted that, although these local strain-rates are an order of magnitude greater than the regional strain-rates measured by Meier, the same is not necessarily the case for stresses. Use of an appropriate flow law, in fact, gives stresses approximately twice those given by regional values.

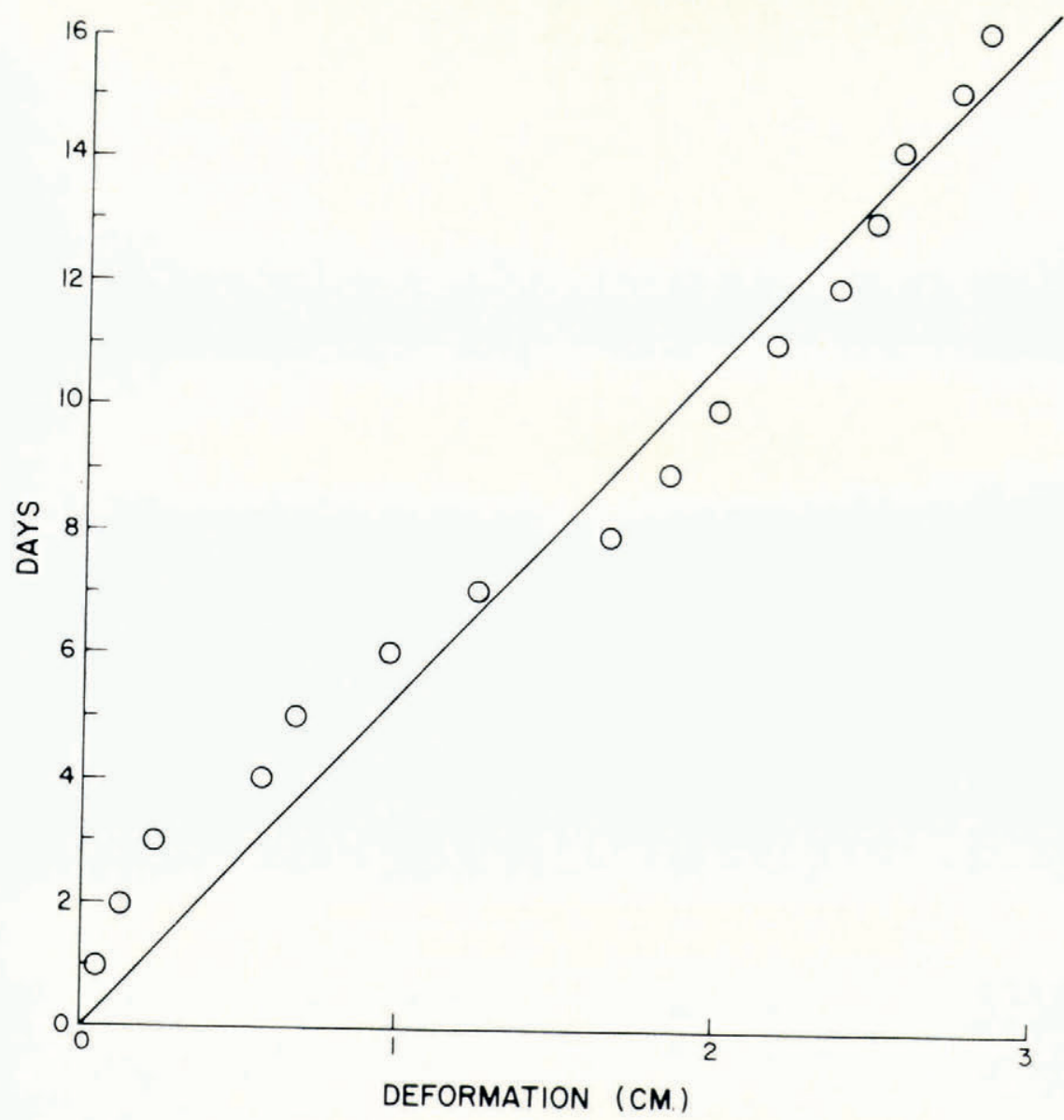

Fig. 4. Deformation between stakes 8 and 9 .

We feel that the unusual results obtained are not due to errors of measurement. The deformation measurements between each pair of stakes are consistent and do not suggest that large random errors occurred. Nor can a consistent motion of the stakes relative to the ice explain the deformations measured over the entire network of stakes. A description of the nature of the ice in this locality and other observations lend credibility to the data.

When seen on an aerial photograph, the crevasse field appears to be reasonably orderly. However, a large number of small fractures appeared and subsequently disappeared during the period of the experiment. These had a typical fracture spacing of $3 \mathrm{~m}$ and were apparently randomly oriented. Additionally the fracture observed between stakes I and 2 healed without developing into a crevasse. The surface was further complicated by the presence of another 
transverse crevasse field some $400 \mathrm{~m}$ up-stream of the site. Crevasses from this field had healed long before they reached the test site. J. Weertman (personal communication) has postulated that crevasses may close at the surface though not at depth and, in fact, such crevasses have been found on the Blue Glacier (LaChapelle, I968). Moulins were present near the test site; these were thought to be a remanent feature of the crevasse field up-stream and, since they were large enough to be draining surface melt water, they probably had a definite effect on the stress distribution around the test site. The nature of the surface and the

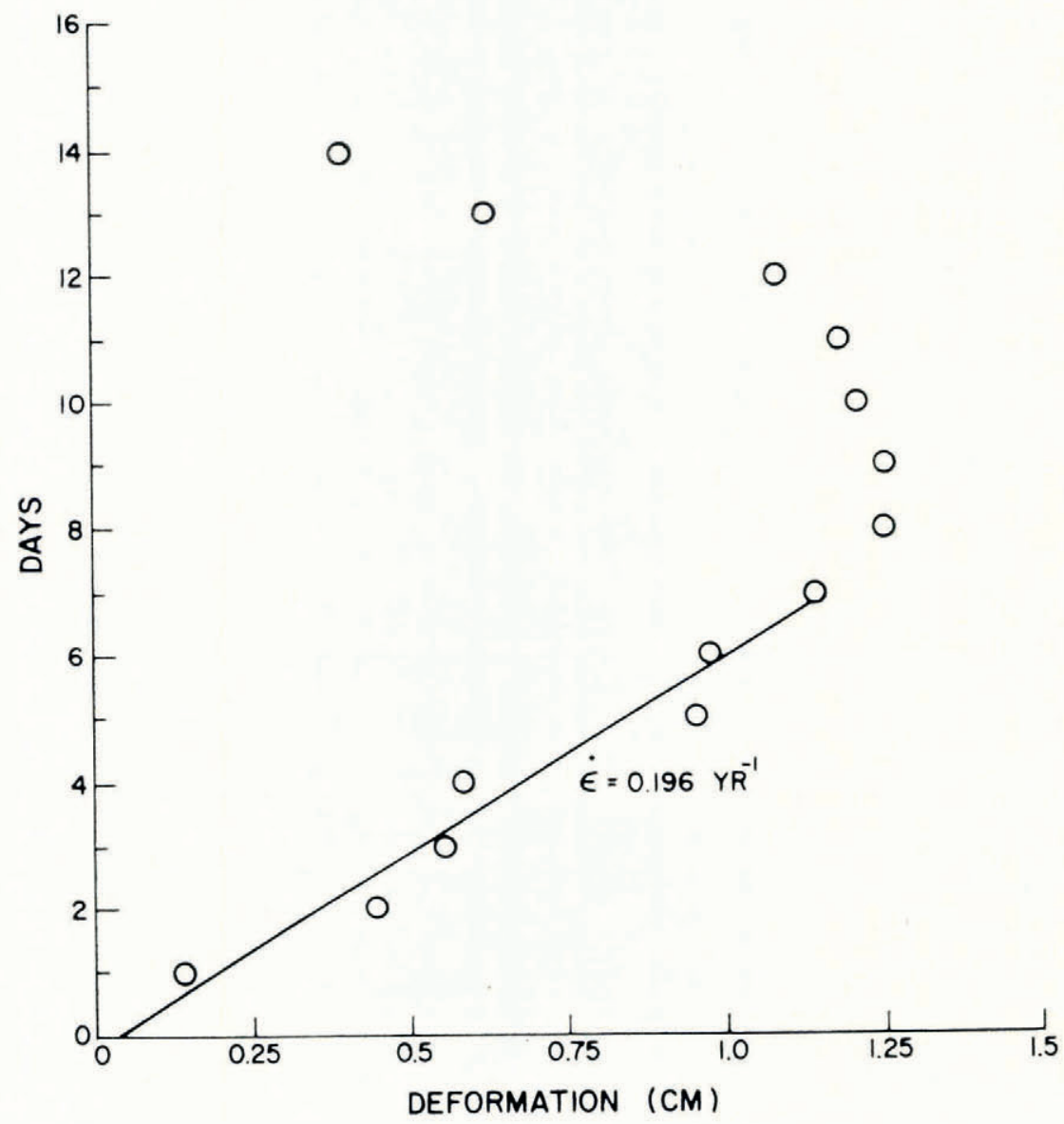

Fig. 5. Deformation between stakes 6 and 7 .

opening and closing of surface fractures is in fact consistent with the data, namely that the state of stress and deformation changes significantly over a distance of a few meters and changes in character over short time intervals.

Such variations on a small scale are consistent with the observations of Meier ( 1960 ) and have been detected in other materials. For example, large fluctuations in surface strain have been measured on concrete specimens after the occurrence of microcracks (Hsu, r968).

The conclusions we draw from the 1968 results are that strain measurements pertinent to the overall glacier flow and to the formation of crevasses cannot be obtained from readings over such small gage lengths as were used here because the presense of surface cracks leads to 
discontinuous displacement fields which undergo large variations over small distances. Thus, although the strain-rate readings may have some significance with regard to stress distribution, strain-rates meaningful to a continuum analysis of regional flow phenomena must be determined by averaging displacement gradients over distances which are large compared with local phenomena, e.g. surface fractures. A reliable estimate of minimum gage length would require a statistical study of surface fracture spacing and orientation as well as knowledge of the effect of such fractures on the distribution of stress and strain-rate. It seems clear, however, that the gage length must be an order of magnitude greater than fracture spacing, i.e. on the order of $30 \mathrm{~m}$.

We do not suggest that such a conclusion is valid for all surface strain measurements. At the transverse crevasse field, as stated above, the structure was complicated by previous fracturing. Although data from the marginal crevasse field in 1967 are not of sufficient accuracy to draw definite conclusions, it appeared that meaningful results could be obtained using a $3 \mathrm{~m}$ gage length. At this location, the ice up-stream from the crevasses was fracturefree and it is suggested that a continuum approach would be meaningful here over dimensions smaller than those for the transverse crevasse field.

MS. received 25 November 1970.

\section{REFERENCES}

Colbeck, S. C., and Evans, R. J. I969. Experimental studies related to the mechanics of glacier flow. Trend in Engineering, Vol. 21, No. 2, p. 8-14.

Holdsworth, G. 1969. Primary transverse crevasses. Fournal of Glaciology, Vol. 8, No. 52, p. 107-29.

Hopkins, W. 1863 . On the theory of the motion of glaciers. Philosophical Transactions of the Royal Society, Vol. 152 , Pt, 2, Art. 31, [for] 1862, p. 677-745.

Hsu, T. T. C. 1968. Torsion of structural concrete plain concrete rectangular sections. ACI Publication, No. SPI 8 , p. $203-38$.

LaChapelle, E. R. 1968. Stress-generated ice crystals in a nearly isothermal two-phase system. Fournal of Glaciology, Vol. 7, No. 5o, p. $183^{-}-98$.

Lachenbruch, A. H. 1961. Depth and spacing of tension cracks. Fournal of Geophysical Research, Vol. 66, No. 12, p. $4273-92$.

Lliboutry, L. A. 1969 . The dynamics of temperate glaciers from the detailed viewpoint. Fournal of Glaciology, Vol. 8, No. 53 , p. $185^{-205}$

Meier, M. F. I960. Mode of flow of Saskatchewan Glacier, Alberta, Canada. U.S. Geological Survey. Professional Paper $35 \mathrm{I}$.

Meier, M. F., and others. 1957. Preliminary study of crevasse formation, by M. F. Meier [and 5 others]. U.S. Snow, Ice and Permafrost Research Establishment. Report 38.

Nye, J. F. 1952. The mechanics of glacier flow. Fournal of Glaciology, Vol. 2, No. 12, p. 82-93. 